Journal of Advanced Research in Fluid Mechanics and Thermal Sciences

Journal homepage: www.akademiabaru.com/arfmts.html ISSN: 2289-7879

\title{
Performance of Crossflow Wind Turbines in In-line Configuration and Opposite Rotation Direction
}

\author{
Zainal Arifin ${ }^{1}$, Dominicus Danardono Dwi Prija Tjahjana ${ }^{1, *}$, Suyitno Suyitno ${ }^{1}$, Wibawa Endra \\ Juwana ${ }^{1}$, Rendhy Adhi Rachmanto ${ }^{1}$, Chico Hermanu Brillianto Apribowo ${ }^{2}$, Catur Harsito ${ }^{3}$

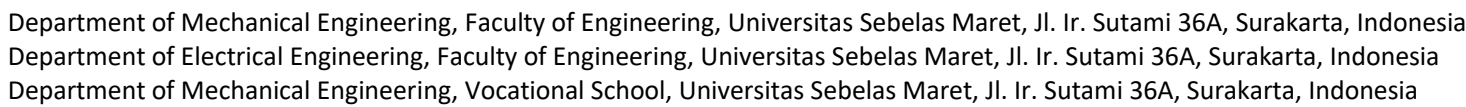

\section{Article history:}

Received 1 September 2020

Received in revised form 21 January 2021

Accepted 23 January 2021

Available online 15 March 2021

\section{Keywords:}

Wind turbine; crossflow; opposite rotation; wind energy; in-line configuration

\begin{abstract}
Wind energy sources must be investigated to produce electrical energy from a renewable source. Crossflow wind turbines are suitable for use because they have several advantages such as self-starting ability, low noise, and excellent stability. They have the potential to be applied as small wind turbines in urban districts because of their small maximum coefficient of power (Cp), which is $10 \%$ of that of other small wind turbines. To enhance the performance of crossflow wind turbines, we changed the turbine to rotate in the opposite direction in the in-line configuration. Turbine performance testing was tested using a wind tunnel. The characteristics of crossflow wind turbines were investigated, then turbine performance was analyzed and discussed. The maximum power coefficient obtained was 0.169 (Cp) with the configuration of 12 turbine blades at a wind speed of $10 \mathrm{~m} / \mathrm{s}$. The maximum torque coefficient obtained was 0.703 . The overall results show that the crossflow wind turbine in in-line configuration with opposite rotation can improve the performance of wind turbines.
\end{abstract}

\section{Introduction}

Energy supply is one of problems currently faced by countries around the world. Fossil fuels remain the main source for generating electrical energy with the help of generators. The wide-scale use of fossil energy has resulted in the scarcity of this resource because it is non-renewable or requires a long time for renewal. As such, R\&D has focused on the field of renewable energy. Wind energy has attracted attention as a renewable energy source to produce electricity [1]. To produce electrical energy from wind energy, a generator is needed to convert the kinetic energy of the wind into electrical energy through a wind turbine system [2-4]. However, wind turbines have some disadvantages: they require strong winds to produce electricity and the investment costs are high.

\footnotetext{
* Corresponding author.

E-mail address: ddanardono@staff.uns.ac.id
}

https://doi.org/10.37934/arfmts.81.1.131139 
Many improvements in wind turbines have been achieved, one of which is the Banki wind turbine as a basic crossflow wind turbine. Crossflow wind turbines have a high torque coefficient at low tip speed ratio, low noise, high stability, and are self-starting [5-8]. Therefore, wind turbines are suitable for use in urban areas as a small wind turbine. The turbine revolves due to wind energy that hits the concave turbine surface area while the other side of the wind pushes the convex turbine surface. The more concave the surface, the higher the torque [9-11].

Eight was the number of blades found to produce the maximum power coefficient value of 0.3 at a relative tip speed ratio of 0.35-0.6 [9]. At wind speeds of $20 \mathrm{~m} / \mathrm{s}$, crossflow wind turbines showed very good performance with a six-blade configuration and turbine dimensions of $152 \mathrm{~mm}$ [12]. The experiment was conducted using the hydrodynamic approach and a full-scale machine that met certain requirements. Research on the number of blades for crossflow wind turbines was performed with 12,15 , and 18 blades. The results showed that the maximum efficiency value of 0.12 was achieved using 12 blades [13]. Mathematical modeling of crossflow wind turbines has also been conducted using ANSYS CFX and varying the speed from 7-11 m/s; the best turbine performance was obtained at low wind speeds with good self-starting capability. The coefficient of power obtained was 0.059 with a tip speed ratio of 0.30 , and the torque coefficient was 0.49 with a tip speed ratio of 0 [14]. Crossflow wind turbine performance is influenced by the number of blades. Previous studies reported that the value of the power coefficient decreases with the number of turbine blades; the wind turbine with 20 blades and size of $1 \times 1 \times 1 \mathrm{~m}$ produced a Coefficient of Power (Cp) of 0.45 and Coefficient of Torque $(\mathrm{Ct})$ of 3.6 with a tip speed ratio below $0.6[15,16]$.

Crossflow wind turbine performance is influenced by the dimensions, blade number, wind speed, and blade shape [6]. Therefore, we aimed to enhance the performance of the crossflow wind turbine in an in-line configuration in the opposite rotation direction. The direction of turbine rotation in crossflow wind turbine systems aims to increase the force acting on the concave blades of the second turbine. The turbine performance is determined using the power and torque coefficient values at a certain tip speed ratio. The power coefficient value is obtained from a comparison between the mechanical power of the rotor and the wind power. The torque coefficient value is obtained from a comparison between actual torque and theoretical torque, whereas the tip speed ratio is the ratio between the rotating speed of the rotor's tip end to the wind speed.

\section{Methodology}

For the experiments in this study, we used a crossflow wind turbine with the specifications as listed in Table 1. We used a wind tunnel with a diffuser, a test section dimension of $30 \times 30 \mathrm{~cm}$, settling chamber, and fan to control the flow velocity. The wind speed in this experiment was set to 8 or $10 \mathrm{~m} / \mathrm{s}$. Figure 1 shows a schematic of the experimental set-up. To achieve opposite rotation direction, an engineered flow was produced using two turbines in which the front turbine functioned to change in the direction of the air flow entering the rear turbine.

Wind speed was measured at three points: $a, b$, and c, using a Pitot Tube Anemometer EXTECH HD350 (PT. Kawan Lama, Surakarta, Indonesia) with an accuracy of $0.97-80 \mathrm{~m} / \mathrm{s}$. Turbine shaft rotational speed was measured using a KRISBOW KW0600563 tachometer (PT. Kawan Lama, Surakarta, Indonesia) with an accuracy of $2-20,000 \mathrm{rpm}(0.05 \%+1 \mathrm{digit})$. Torque values were obtained using a Prony brake system and calculations using effective force and effective radius, as shown in Figure 2. 
Table 1

Turbine specifications

\begin{tabular}{ll}
\hline Parameter & Value \\
\hline Outer Diameter $\left(D_{0}\right)$ & $200 \mathrm{~mm}$ \\
Inner Diameter $\left(D_{1}\right)$ & $130 \mathrm{~mm}$ \\
Turbine Height $(H)$ & $200 \mathrm{~mm}$ \\
Aspect Ratio $\left(D_{1} / H\right)$ & 1 \\
Overlap ratio & 0 \\
Blades Length & $60,25 \mathrm{~mm}$ \\
Blades Number & 12,16, and 20 \\
\hline
\end{tabular}

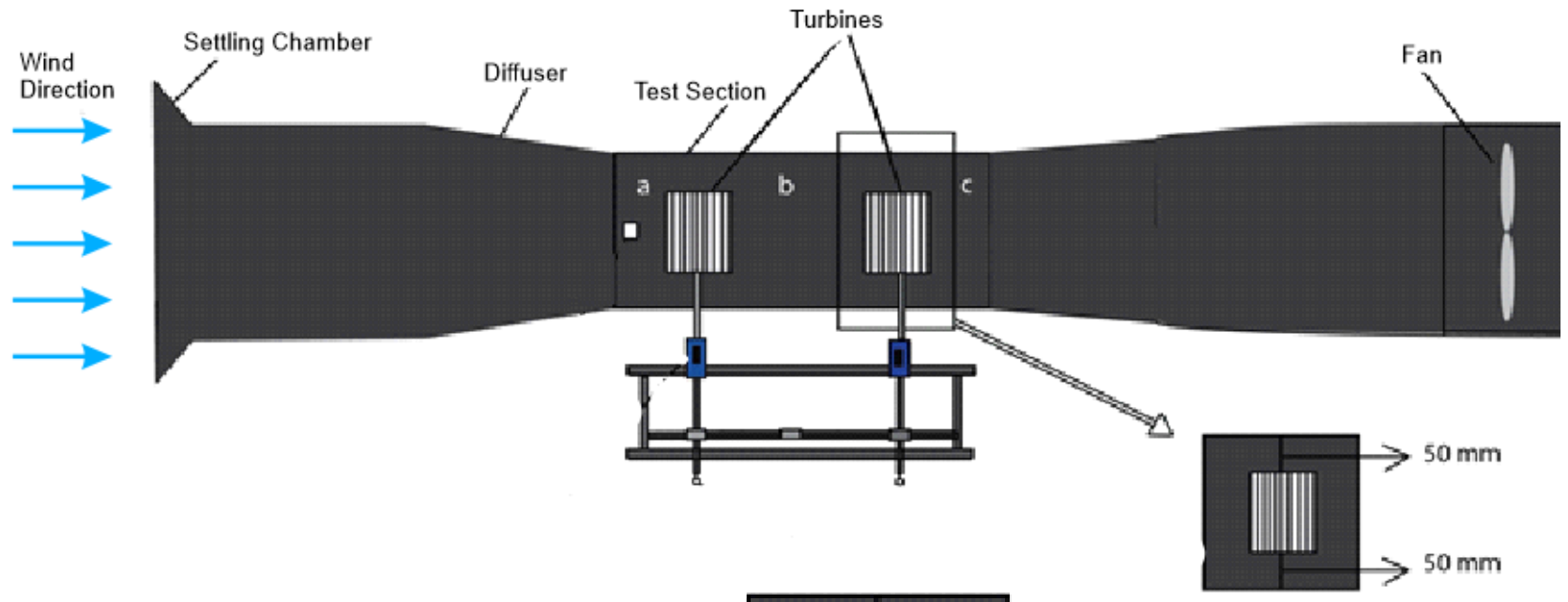

Wind Velocity Measurement Point

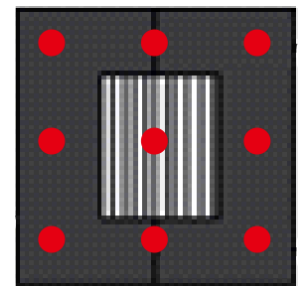

Fig. 1. Experimental set-up test

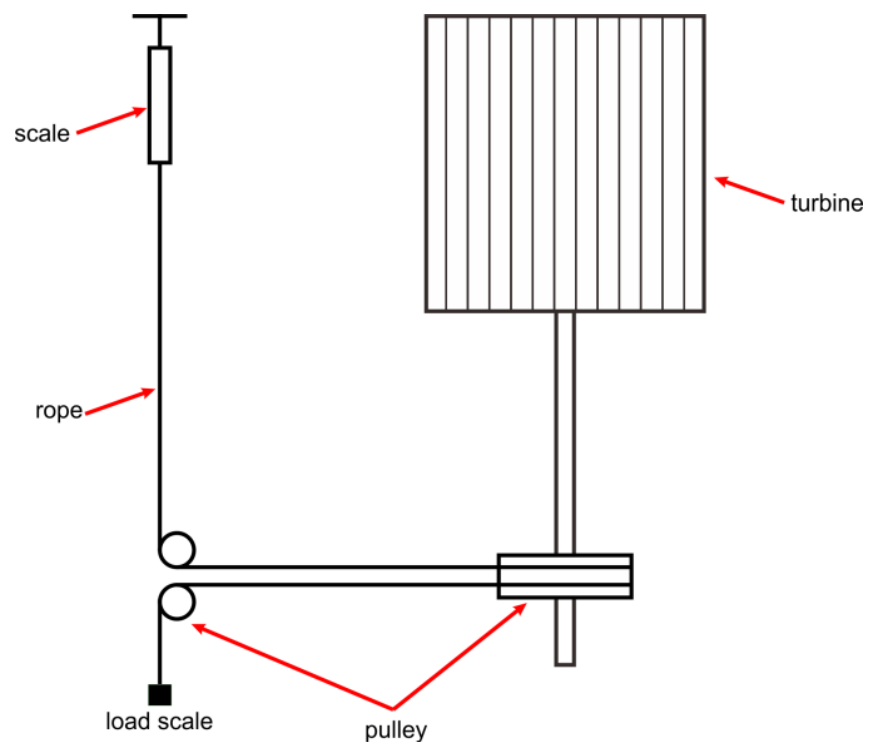

Fig. 2. Prony brake system 
The crossflow wind turbine was designed by SolidWorks 2016 and fabricated in ATMI Duta Engineering (Surakarta, Indonesia). Turbines were constructed with $5 \mathrm{~mm}$ thick aluminum material. Figure 3 shows the dimensions of the turbine used in this study with a 1:1 aspect ratio, outer turbine diameter of $200 \mathrm{~mm}$, inner turbine diameter of $130 \mathrm{~mm}$, turbine radius of $60.25 \mathrm{~mm}$, and turbine height of $200 \mathrm{~mm}$. In this study, we also varied the number of blades using 12, 16, and 20 blades.

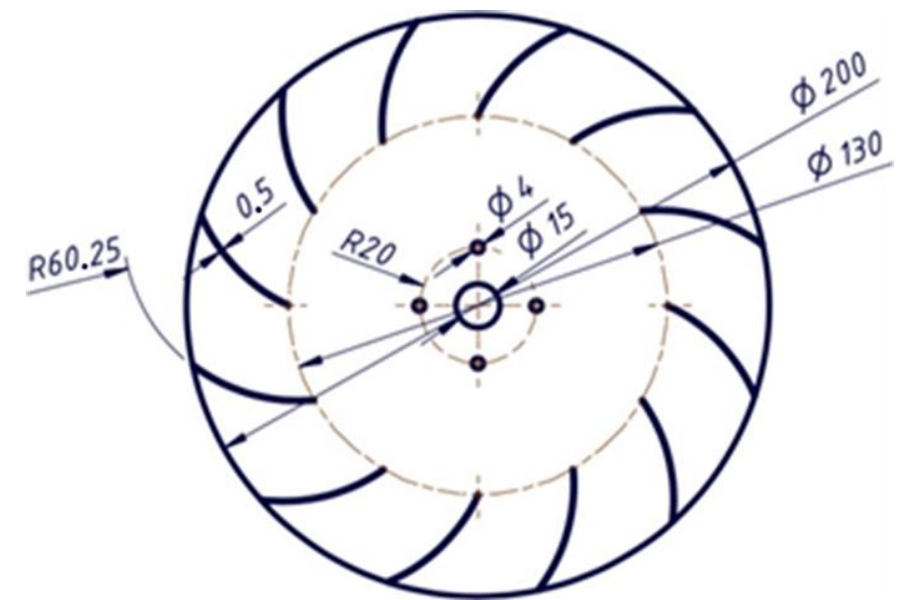

(a)

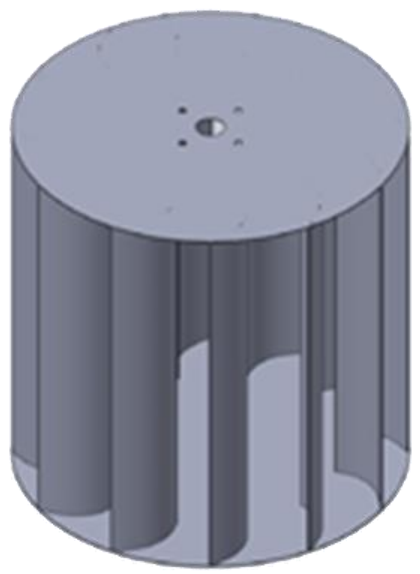

(b)

Fig. 3. Crossflow wind turbine configuration (a) dimension; (b) 3D view

\section{Results}

\subsection{Turbine Performance}

Performance of front wind turbine is shown in Figure 4 for the different wind speeds. Based on the experiment, the maximum turbine power coefficient value was 0.161 velocity $(\mathrm{V}=8 \mathrm{~m} / \mathrm{s})$ on Tip Speed Ratio (TSR) 0.518, $0.122(\mathrm{~V}=10 \mathrm{~m} / \mathrm{s})$ on TSR $0.415,0.675(\mathrm{~V}=8 \mathrm{~m} / \mathrm{s})$ on TSR 0.027 , and 0.628 $(\mathrm{V}=10 \mathrm{~m} / \mathrm{s})$ on TSR 0.027 . These values align with those reported by Ushiyama et al., in which a wind turbine with 12 blades produced the best performance [13].

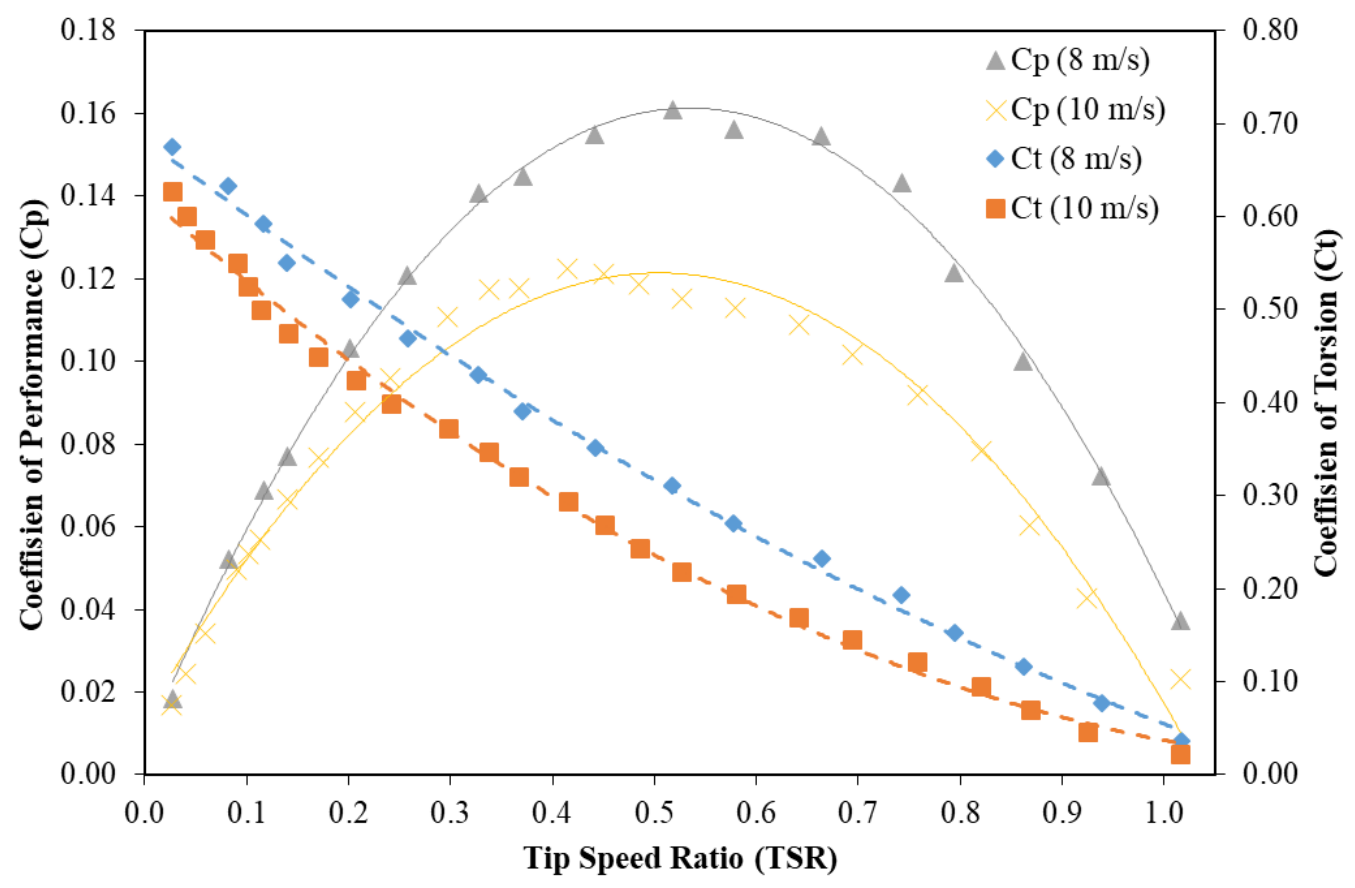

Fig. 4. Performance of the front turbine 
The performance of the turbine was similar to that reported in previous studies in which the $\mathrm{Cp}$ value increased with increasing TSR and reached a peak at a certain TSR then decreased, forming a parabolic curve [17], because the experiment was conducted using the close circuit environmental wind tunnel method, which produces uniform airflow [18]. The Ct results formed an exponential curve with the value of $\mathrm{Ct}$ tending to decrease with increasing TSR [19].

To differentiate the effects of Reynolds number (Re), the experiments were also performed at two speeds, 8 and $10 \mathrm{~m} / \mathrm{s}$. Re was calculated using Eq. (1) (see Table 2).

Table 2

The values of Reynolds number and velocity

\begin{tabular}{ll}
\hline Reynolds number (Re) & Velocity (V) \\
\hline $9.52 \times 10^{3}$ & $8 \mathrm{~m} / \mathrm{s}$ \\
$1.19 \times 10^{4}$ & $10 \mathrm{~m} / \mathrm{s}$ \\
\hline
\end{tabular}

$R e=\frac{\rho V D}{\mu}$

where $\mu$ is the dynamic viscosity, $\rho$ is the density of air, and $D$ is length, which were $1.983 \times 10^{-5}$ $\mathrm{kg} / \mathrm{ms}, 1.18 \mathrm{~kg} / \mathrm{m}^{3}$, and $0.02 \mathrm{~m}$, respectively.

\subsection{Effect of Number of Blades}

The performance of crossflow wind turbines can be determined using the value of the power coefficient. In this study, we tested turbines with 12,16, or 20 blades at wind speeds of 8 and $10 \mathrm{~m} / \mathrm{s}$. Figure 5 shows the power coefficient obtained from the experiment at a wind speed of $10 \mathrm{~m} / \mathrm{s}$ with 12,16 , and 20 blades. The maximum power coefficient was produced from the wind turbine with 12 blades, at 0.168 . Increasing the number of blades did not increase the power coefficient.

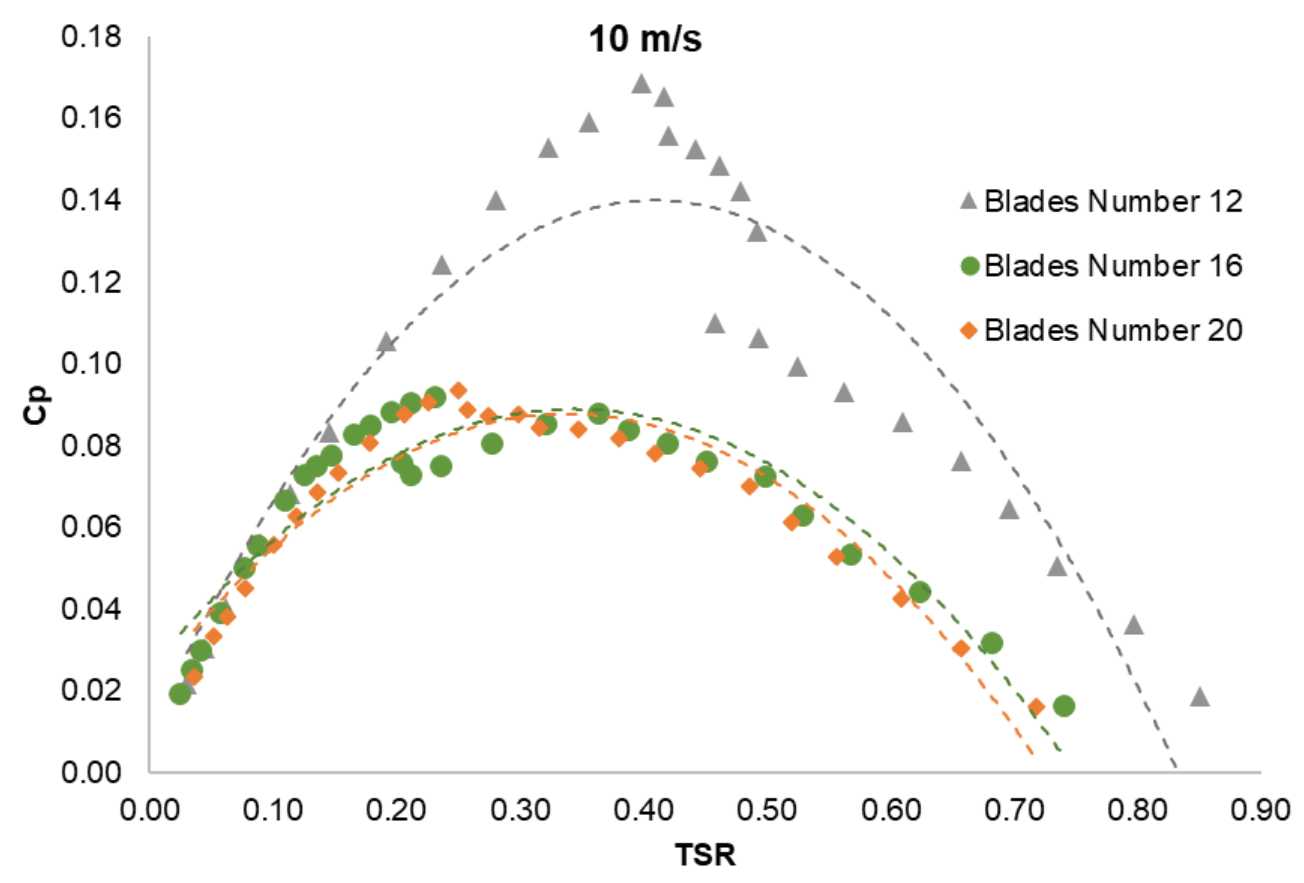

Fig. 5. Power coefficient of crossflow wind turbine at a wind speed of $10 \mathrm{~m} / \mathrm{s}$ 
Figure 6 shows the results of the power coefficient of a crossflow wind turbine at a wind speed of 8 $\mathrm{m} / \mathrm{s}$. A parabolic trend similar to the results of the power coefficient at a wind speed of $10 \mathrm{~m} / \mathrm{s}$ was found. Figure 6 shows that the highest power coefficient at a wind velocity of $8 \mathrm{~m} / \mathrm{s}$ was 0.096 at TSR 0.362 with 20 blades. Increasing the number of turbine blades created fewer gaps among the blades, producing wind flow that could pass through, resulting in increasingly negative torque.

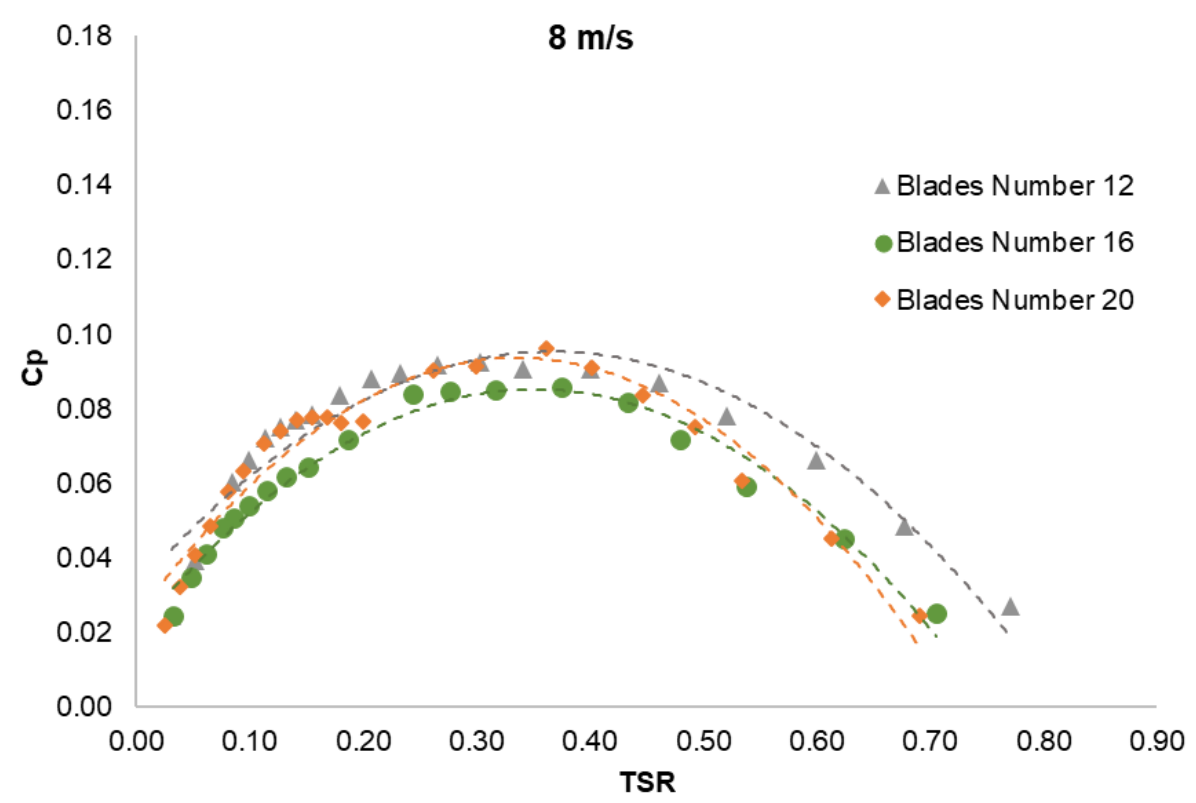

Fig. 6. Power coefficient of crossflow wind turbine at a wind speed of $8 \mathrm{~m} / \mathrm{s}$

Figure 7 shows the maximum coefficient power in the investigation. The higher the number of blades, the lower the coefficient of power. The highest coefficient power was produced by a turbine with 12 blades and an air velocity of $10 \mathrm{~m} / \mathrm{s}$. This value is a $5 \%$ increase over the standard wind turbine. Using more blades decreased the coefficient of power.

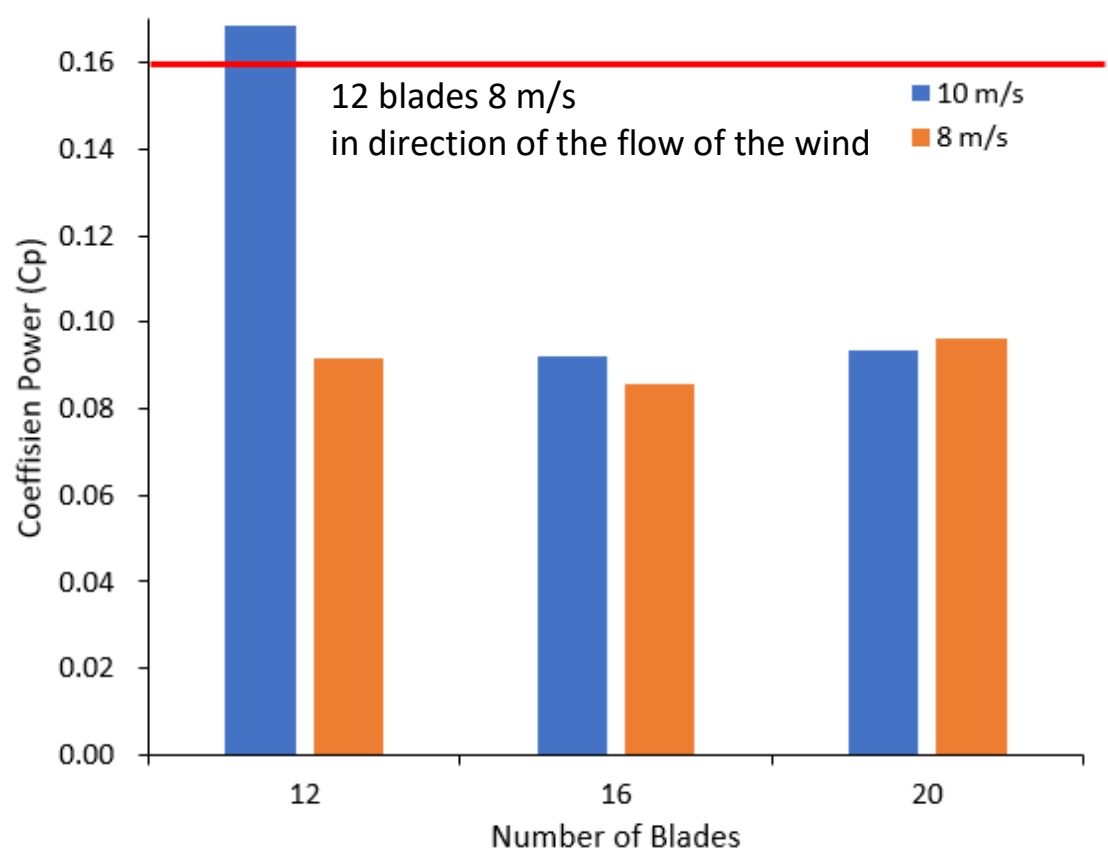

Fig. 7. Changes in coefficient of power with number of blades at different wind speeds 
This is in agreement with previous studies in which the use of more blades resulted in a decrease in the coefficient of power, which was caused by obstructed airflow due to increasingly small gaps among the turbines, leading to increased negative torque as well as turbulence in front of the turbine [20].

\subsection{Torque Coefficient of Crossflow Wind Turbine}

The ability of a turbine to rotate when obtaining wind energy can be understood from the value of the torque coefficient. Figure 8 compares the torque coefficient value and the tip speed ratio at wind velocities of 8 and $10 \mathrm{~m} / \mathrm{s}$. The torque coefficient decreases with increasing tip speed ratio, forming an exponential curve [21].

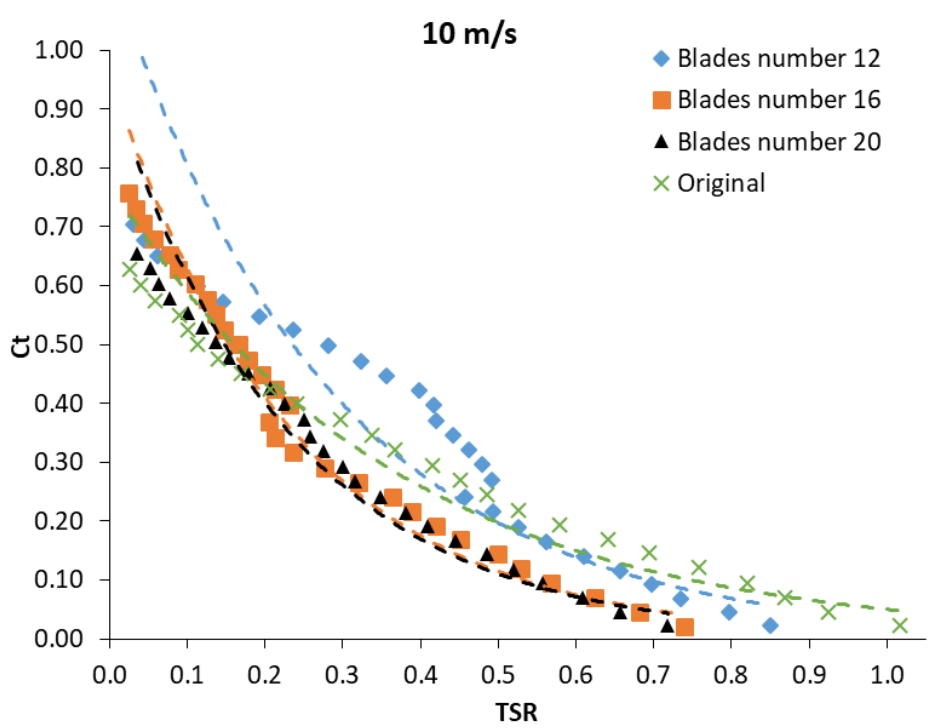

(a)

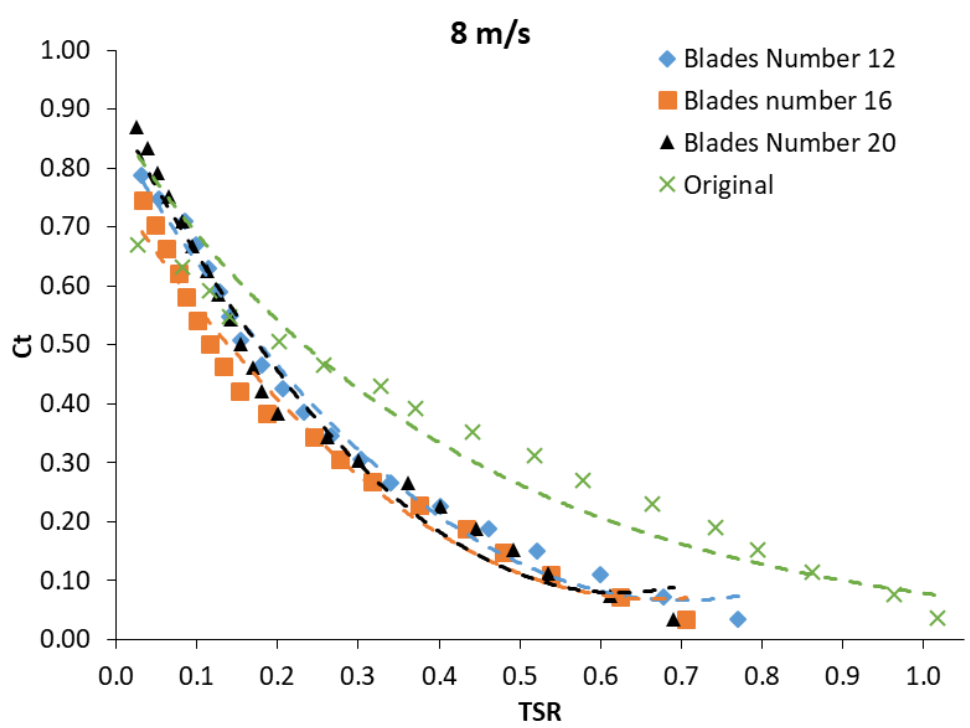

(b)

Fig. 8. Effect of number of blades on torque coefficient at (a) 10 and (b) $8 \mathrm{~m} / \mathrm{s}$ 
This occurred because the experimental process was performed using Prony brake system that was gradually loaded until the turbine stopped revolving. A turbine with a wind speed of $10 \mathrm{~m} / \mathrm{s}$ and 16 blades produced the best torque coefficient value of 0.757 at TSR 0.025 . At a wind velocity of 8 $\mathrm{m} / \mathrm{s}$, the highest torque coefficient was 0.870 at TSR 0.025 with 20 blades. This occurred due to the large number of fields affected by the wind kinetic energy for the turbine blade producing a large amount of torque.

The torque coefficient value for the wind turbine at a wind velocity $8 \mathrm{~m} / \mathrm{s}$ was above the standard turbine coefficient value. The increase in the value of the torque coefficient is shown in Figure 9; the maximum torque coefficient in this study is higher than the standard torque coefficient (0.675 at TSR $0.025)$. The torque coefficient at high wind velocity was lower than that at low wind velocity. At high velocity, the flow of air hitting the turbine was imperfect due to the low wind momentum and the high number of blades that increased the negative torque [19]. However, at a wind velocity of $8 \mathrm{~m} / \mathrm{s}$, the highest torque coefficient was produced by the turbine with 20 blades because of air flow that hit the turbine perfectly, as well as the negative torque produced that was lower than positive torque. This is what creates the ability of the wind to revolve the turbine.

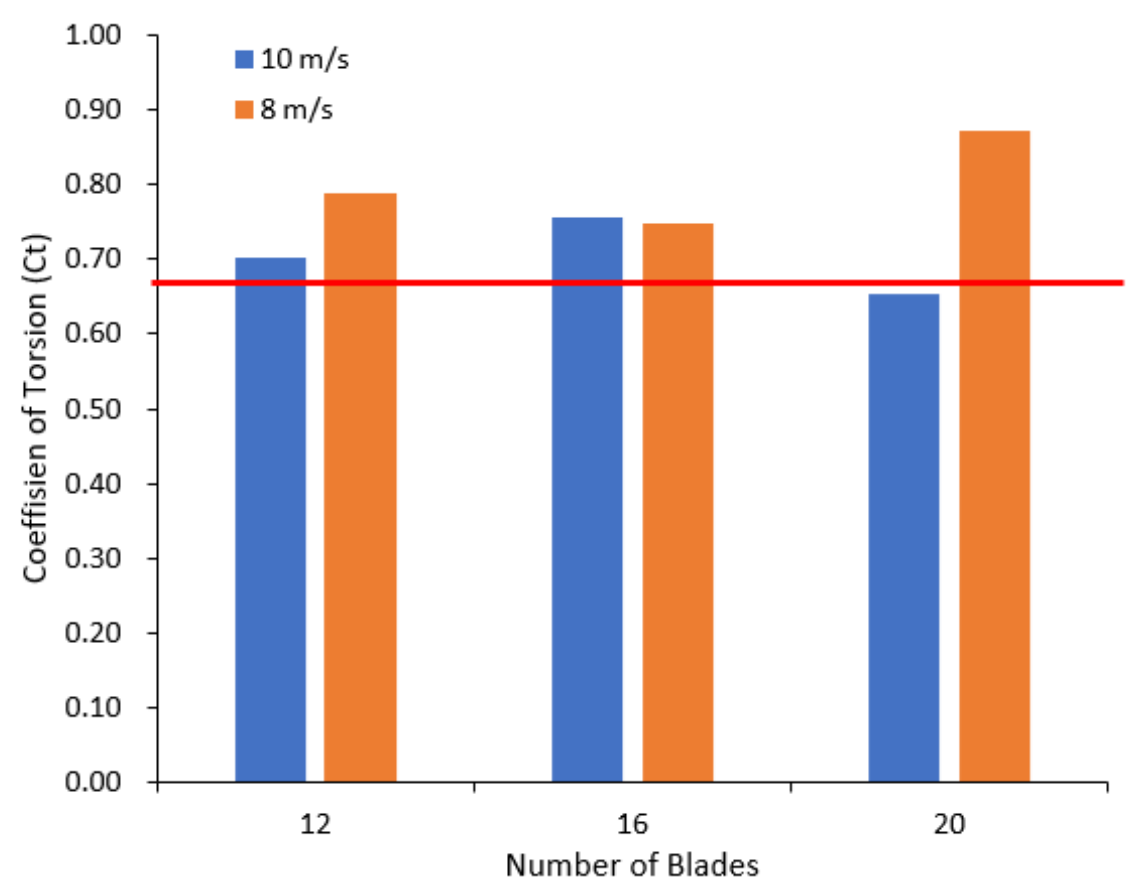

Fig. 9. Maximum torque coefficients for different numbers of blades

\section{Conclusions}

Based on the results of the investigation of crossflow wind turbines, we successfully constructed a crossflow wind turbine with opposite rotation. The wind velocity and number of turbine blades influence the power coefficient. The crossflow wind turbine with 12 blades at a wind velocity of 10 $\mathrm{m} / \mathrm{s}$ produced the largest power coefficient with a torque coefficient value higher than the standard wind turbine ( 0.169 and 0.703 , respectively).

\section{Acknowledgements}

This research was fully supported by PNBP grant from the Sebelas Maret University, Indonesia, with contract number 452/UN27.21/PN/2020. 


\section{References}

[1] Fukutomi, Junichiro, Toru Shigemitsu, and Hiroki Daito. "Study on performance and flow condition of a cross-flow wind turbine with a symmetrical casing." Journal of Fluids Engineering 133, no. 5 (2011). https://doi.org/10.1115/1.4004023

[2] Mathew, Sathyajith. Wind energy: fundamentals, resource analysis and economics. Springer, 2006.

[3] Yudi Kurniawan, Dominicus Danardono Dwi Prija Tjahjana, and Budi Santoso. "Experimental Study of Savonius Wind Turbine Performance with Blade Layer Addition." Journal of Advanced Research in Fluid Mechanics and Thermal Science 69, no. 1 (2020): 23-33. https://doi.org/10.37934/arfmts.69.1.2333

[4] Harsito, Catur, Dominicus Danardono Dwi Prija Tjahjana, and Budi Kristiawan. "Savonius turbine performance with slotted blades." In AIP Conference Proceedings, vol. 2217, no. 1, p. 030071. AIP Publishing LLC, 2020.

[5] Montelpare, Sergio, Valerio D'Alessandro, Andrea Zoppi, and Renato Ricci. "Experimental study on a modified Savonius wind rotor for street lighting systems. Analysis of external appendages and elements." Energy 144 (2018): 146-158. https://doi.org/10.1016/j.energy.2017.12.017

[6] Akwa, Joao Vicente, Horacio Antonio Vielmo, and Adriane Prisco Petry. "A review on the performance of Savonius wind turbines." Renewable and sustainable energy reviews 16, no. 5 (2012): 3054-3064. https://doi.org/10.1016/i.rser.2012.02.056

[7] Jha, Asu Ram. Wind turbine technology. CRC press, 2010. https://doi.org/10.1201/9781439815076

[8] Yang, Bo, and Chris Lawn. "Fluid dynamic performance of a vertical axis turbine for tidal currents." Renewable Energy 36, no. 12 (2011): 3355-3366. https://doi.org/10.1016/j.renene.2011.05.014

[9] Al-Maaitah, Ayman A. "The design of the Banki wind turbine and its testing in real wind conditions." Renewable energy 3, no. 6-7 (1993): 781-786. https://doi.org/10.1016/0960-1481(93)90085-U

[10] Polagye, Brian, Ben Strom, Hannah Ross, Dominic Forbush, and Robert J. Cavagnaro. "Comparison of cross-flow turbine performance under torque-regulated and speed-regulated control." Journal of Renewable and Sustainable Energy 11, no. 4 (2019): 044501. https://doi.org/10.1063/1.5087476

[11] Bachant, Peter, Martin Wosnik, Budi Gunawan, and Vincent S. Neary. "Experimental study of a reference model $\begin{array}{llllll}\text { vertical-axis cross-flow turbine." PloS one 11, no. } 9 & \text { (2016): } & \text { e0163799. }\end{array}$ https://doi.org/10.1371/journal.pone.0163799

[12] Sivasegaram, S. "An experimental investigation of a class of resistance-type, direction-independent wind turbines." Energy 3, no. 1 (1978): 23-30. https://doi.org/10.1016/0360-5442(78)90053-1

[13] Seralathan, Sivamani, Micha Premkumar Thomai, Rian Leevinson Jayakumar, Basireddy Venkata Lokesh Reddy, and Hariram Venkatesan. "Experimental and Numerical Assessment of Cross Flow Vertical Axis Wind Turbine." In Gas Turbine India Conference, vol. 83532, p. V002T06A006. American Society of Mechanical Engineers, 2019.

[14] Seralathan, Sivamani, Micha Premkumar Thomai, Rian Leevinson Jayakumar, Basireddy Venkata Lokesh Reddy, and Hariram Venkatesan. "Experimental and Numerical Assessment of Cross Flow Vertical Axis Wind Turbine." In Gas Turbine India Conference, vol. 83532, p. V002T06A006. American Society of Mechanical Engineers, 2019.

[15] Colley, Gareth, Rakesh Mishra, H. V. Rao, and R. Woolhead. "Performance evaluation of three cross flow vertical axis wind turbine configurations." University of Huddersfield, 2009.

[16] Dragomirescu, A. "Performance assessment of a small wind turbine with crossflow runner by numerical simulations." Renewable energy 36, no. 3 (2011): 957-965. https://doi.org/10.1016/i.renene.2010.07.028

[17] Roy, Sukanta, and Ujjwal K. Saha. "Wind tunnel experiments of a newly developed two-bladed Savonius-style wind turbine." Applied Energy 137 (2015): 117-125. https://doi.org/10.1016/i.apenergy.2014.10.022

[18] Ricci, Renato, Roberto Romagnoli, Sergio Montelpare, and Daniele Vitali. "Experimental study on a Savonius wind rotor for street lighting systems." Applied Energy 161 (2016): 143-152. https://doi.org/10.1016/j.apenergy.2015.10.012

[19] Kurniawati, Diniar Mungil, Dominicus Danardono Dwi Prija Tjahjana, and Budi Santoso. "Experimental investigation on performance of crossflow wind turbine as effect of blades number." In AIP Conference Proceedings, vol. 1931, no. 1, p. 030045. AIP Publishing LLC, 2018. https://doi.org/10.1063/1.5024104

[20] Tjahjana, Dominicus Danardono Dwi Prija, Syamsul Hadi, Yoga Arob Wicaksono, Diniar Mungil, Fahrudin Kurniawati, Ilham Satrio Utomo, and Sukmaji Indro Cahyono andAri Prasetyo. "Study on Performance Improvement of the Savonius Wind Turbine for Urban Power System with Omni-directional Guide Vane (ODGV)." Journal of Advanced Research in Fluid Mechanics and Thermal Sciences 55, no. 1 (2019): 126-135.

[21] Kamoji, M. A., Shireesh B. Kedare, and S. V. Prabhu. "Experimental investigations on single stage modified Savonius rotor." Applied Energy 86, no. 7-8 (2009): 1064-1073. https://doi.org/10.1016/j.apenergy.2008.09.019 